\title{
Four Decades of Family Policy, Counseling, Research
}

\section{AIMO PULKKINEN}

Director, Population Research Institute

Right now you have in your hands the Yearbook of Population Research in Finland, volume XIX. The first yearbook in English was published in 1971. In the beginning it came out every second year, later on annually. It was preceeded by a Finnish language yearbook, the publication of which started already in the mid-1940s, with English summaries added in the beginning of the 1960s.

The publisher of the yearbook is the Population Research Institute founded in 1946 as a department of the Finnish Population and Family Welfare Federation, Väestöliitto. Since Väestöliitto celebrates its 40th anniversary this year and at the same time 35 years have passed from the foundation of the Population Research Institute, it may be appropriate to tell a few words on their background, aims and recent activities.

Väestöliitto, the Finnish Population and Family Welfare Federation, is a private population and family policy organization comprising 24 groups and societies; the Ministry for Social Affairs and Health is also represented in its administrative board. Väestöliitto is granted state subsidies but it is neutral and apolitical. It has the right to free action and it can criticize both the Cabinet and the Parliament. But at the same time the organization has a semiofficial standing which can be seen in many forms. The government has in several cases entrusted it with the administration of acts connected with family welfare.

Väestöliitto has several international relationships and it is a member of the IPPF, the International Planned Parenthood Federation, and the IUFO, the International Union of Family Organisations. Its task is to follow population development, to make initiatives in the field of population, family and housing policy, to participate in committees and to spread information on population to the authorities, political parties, labor market, economic life and civic organizations and also to the mass media: press, radio and television. In order to spread information on population and family policy, Väestöliitto publishes two magazines and organizes conferences, symposia and meetings.

It is also responsible for the national celebration on Mother's Day on the second Sunday in May. 
Population and family policy is dependent on the development of social and economic policy. That is why in addition to population and family policy, housing policy, home help services and public health policy especially are of main interest to Väestöliitto. Among the most important achievements of Väestöliitto are the initiatives for bills on child allowances, housing loans granted by the state, housing subsidies to families with children as well as homemaker training and marriage counselling. Since the activities of Väestöliitto are manifold it needs several departments which specialize in various forms of activities and services.

Preparation of family policy initiatives, development of family education, family guidance and the public health work of the Federation belong to the Family Affairs Office. The main activity of the clinics, which work under the Office, is spreading information about family guidance and family planning. The work dealing with family guidance is aimed at helping people with problems such as lack of compatibility in marriage, sexual problems, infidelity, jealousy, excessive use of alcohol, conflicts during dating and engagement or various other difficulties in human relations. Family planning guidance consists of contraceptive counselling and the insertion of IUDs, the examination and treatment of complications arising from the use of the IUD and other contraceptive methods and dealing with matters connected with sterilization and infertility. The staff of the guidance clinics consists of gynecologists, psychiatrists, psychologists, lawyers, social counsellors and nurses. In this connection it must be mentioned that Väestöliitto also owns three marketing companies selling contraceptives in order to make family planning successful: every child should be born wanted.

Väestöliitto also includes a department of medical genetics counselling. The aim of this department is to gain knowledge about hereditary diseases, give consultative aid to physicians in problems of unusual hereditary diseases, the mapping and investigation of hereditary diseases in Finland and to give information concerning these matters.

General questions concerning the development of home aid services and the administration of homemaker training also belong to the activities of Väestöliitto. The training course and the examination are completed at the Homemaker Institute. Homemakers work as communal homekeepers, in children's homes and day-care organizations and in the field of home nursing, at old people's homes and in private homes.

\section{The Population Research Institute}

Since 1946 Väestöliitto has had its own research institute, the Population Research Institute. However, the social reform work of Väestöliitto was based on scientific research from the very beginning. Thus the Population Research Institute took over the research work done earlier. 
The Population Research Institute has established itself among the research institutes in Finland and created firm and manysided contacts with corresponding research institutes abroad. On the initiative both of Väestöliitto and other institutions the institute draws up surveys and investigations concerning population, family and housing; it also prepares for Väestöliitto separate reports and calculations which benefit the family policy reform work of Väestöliitto or which are promulgated at request directly to the authorities, political parties or to the Parliament and the Cabinet.

The yearbook tries to shed light on the population situation in Finland and its continuous development, and it is unique in its field in the Nordic countries. It makes an international exchange of ideas possible by presenting the newest demographic studies published in Finland and by expressing opinions and attitudes on topical problems concerning population, family and housing.

In addition to the yearbook the Institute has three separate publication series, in which research reports are published mainly in Finnish.

The first important task of the Institute in the mid-1940s was the examination of the consequences of the extensive post war movement from the rural areas to the urban areas. During the 1950 s the focus was mainly on the growing housing problem. In the sixties several different studies mainly on different population and social policy questions were published. Mostly the studies have represented applied science and current problems and have been efforts to supply the decision makers with needed information.

In the 1970 s international research projects were given more space in the program of the Population Research Institute. A few examples will shed light on the character of these joint efforts.

At the beginning of the seventies the Institute represented Finland in the joint working group for the study of legislation directly or indirectly influencing fertility in Europe. This took place in connection with a joint project of the European Centre for Co-ordination of Research and Documentation in the Social Sciences, and the IUSSP, the International Union for the Scientific Studies of Population. After three years' work in the middle of the decade, the findings were issued in two volumes, Law and Fertility in Europe.

At the same time another international study was being carried out. This study was prepared by the secretariat of the Economic Commission for Europe, acting in cooperation with the Division of Social Affairs of the United Nations' office at Geneva and its Working Group on Social Demography. The Institute was represented in this working group and Finland was also included in the final report: Fertility and Family Planning in Europe Around 1970: A comparative study of twelve national surveys.

Already before the previous study was published, a large population survey on the international level took its first steps. The World Fertility Survey was begun and a few years later Finland was also able to report its participation in this study. The study is being carried out by the Institute in cooperation with the Department of Social Policy, at the University of Helsinki. The first 
international part of the WFS has already been finished, although further analyses are being continued to determine factors affecting fertility behavior and family size. The Institute continues to be represented in the UN Working Group on Social Demography, and in connection with the study in question, the Institute is participating in the ECE/WFS Comparative Study on Fertility and Family Planning in Europe and the United States.

Among other international projects in which the Institute participated during the mid-1970s was a systematic survey of comparative family policy carried out in fourteen countries in Western and Eastern Europe as well as in North America. This study was part of a social service and family policy research program at Columbia University in the USA.

In addition to the active contribution to international research cooperation, the Institute has done its best in spreading and maximizing the use of the data related to research findings. So far the most significant event of this kind was the first specialized IUSSP-conference on Economic and Demographic Change; Issues for the 1980's, which was held in Helsinki in 1978. The Finnish Population and Family Welfare Federation represented by the Population Research Institute, the Central Statistical Office of Finland and the Demographic Society in Finland acted as the Finnish hosts for this conference, in which nearly 400 scientists from different parts of the world took part. 